\title{
KAJIAN EFEKTIVITAS PENGGUNAAN ANTIBIOTIK PADA PASIEN INFEKSI SALURAN KEMIH (ISK) DI RUMAH SAKIT SAMARINDA MEDIKA CITRA (SMC) KOTA SAMARINDA
}

\author{
Risa Yusnita*, Lisna Meylina, Arsyik Ibrahim, Laode Rijai \\ Laboratorium Penelitian dan Pengembangan FARMAKA TROPIS \\ Fakultas Farmasi Universitas Mulawarman, Samarinda, Kalimantan Timur \\ *email : risayusnita15@gmail.com
}

\begin{abstract}
ABSTRAK
Infeksi Saluran Kemih (ISK) merupakan infeksi yang paling umum terjadi di masyarakat yang mengakibatkan kenaikan secara signifikan angka kejadian morbiditas serta mortilitas. Efektivitas penggunaan antibiotika akan berperan penting dalam pengobatan ISK, oleh karena itu dilakukan penelitian kajian efektivitas penggunaan antibiotika pada pasien Infeksi Saluran Kemih (ISK) di Rumah Sakit Samarinda Medika Citra (SMC) Periode Desember 2014 - Desember 2016. Berdasarkan hasil penelitian, maka dapat disimpulkan angka kejadian ISK dengan jenis kelamin pria $21 \%$ dan wanita $79 \%$, serta angka kejadian ISK terbesar pada rentan usia 17 - 35 tahun baik pada pria ataupun wanita. Jenis antibiotika yang digunakan antara lain, seftriakson, sefotaksim, sefiksim, siprofloksasin, levofloksasin, amoksisilin, ampisilin dan kombinasi sefoperazone dengan sulfabaktam. Kesesuaian penggunaan antibiotika pada pasien ISK di Rumah Sakit Samarinda Medika Citra (SMC) belum sepenuhnya sesuai dengan pedoman diagnosis dan terapi Rumah Sakit Samarinda Medika Citra (SMC) dan efektivitas penggunaan antibiotika pada pasien ISK di Rumah Sakit Samarinda Medika Citra (SMC) sepenuhnya efektif berdasarkan kondisi pasien.
\end{abstract}

Kata Kunci : Infeksi Saluran Kemih, Antibiotika, Efektivitas

\begin{abstract}
Urinary Tract Infection (UTI) is the most common infection in communities cause increase significantly of the morbidity and mortality incidence value. The effectiveness of using antibiotics will have a important role in urinary tract infection treatment. Based on the result of research, it can be concluded that the Urinary Tract Infection's incidence with male is $21 \%$ and female is $79 \%$, and the highest Urinary Tract Infection's incidence at age 17 - 35 years old in both of their. The types of antibiotics used are ceftriaxone, cefotaxime, cefixime, ciprofloxacin, levofloxacin, amoxicillin, ampicillin and combination of cefoperazone and sulfabactam. The suitability of using antibiotics in Urinary Tract Infection patients at Samarinda Medika Citra (SMC) Hospital isn't entirely suitable with Samarinda
\end{abstract}


Medika Citra (SMC) Hospital's Diagnosis and Treatment Guidelines and the effectiveness of using antibiotics in Urinary Tract Infection patients at Samarinda Medika Citra (SMC) Hospital is entirely effective based on patient's condition.

Keywords : Urinary Tract Infection, Antibiotics, Effectiveness

\section{PENDAHULUAN}

Sistem perkemihan merupakan suatu sistem dimana terjadinya proses penyaringan darah sehingga darah bebas dari zat yang tidak dipergunakan oleh tubuh dan menyerap zat yang masih dipergunakan oleh tubuh. Zat yang tidak dipergunakan oleh tubuh larut dalam air dan dikeluarkan berupa urin (Speakman, 2008).

Infeksi Saluran Kemih (ISK) merupakan istilah umum yang menunjukkan keberadaan mikroorganisme dalam urin. ISK keadaan ditemukannya mikrorganisme di dalam urin dalam jumlah tertentu. Pasien didiagnosis ISK bila urinnya mengandung lebih dari $10^{5}$ bakteri/mL (Coyle, 2005).

Umumnya ISK disebabkan oleh kuman gram negatif. Escherichia coli merupakan penyebab terbanyak baik pada yang simtomatik maupun yang asimtomatik yaitu 70-90\%. Enterobakteria seperti Proteus mirabilis (30\% dari infeksi saluran kemih pada anak laki-laki tetapi kurang dari 5\% pada anak perempuan), Klebsiella pneumonia dan Pseudomonas aeruginosa dapat juga sebagai penyebab. Organisme gram positif seperti Streptococcus faecalis (enterokokus), Staphylococcus epidermidis dan Streptococcus viridans jarang ditemukan.

Penggunaan antibiotik adalah pilihan utama dalam pengobatan infeksi saluran kemih. Pemakaian antibiotik secara efektif dan optimal memerlukan pengertian dan pemahaman mengenai bagaimana memilih dan memakai antibiotik secara benar. Pemilihan berdasarkan indikasi yang tepat, menentukan dosis, cara pemberian, lama pemberian, maupun evaluasi efek antibiotik. Pemakaian dalam klinik yang menyimpang dari prinsip dan pemakaian antibiotik secara rasional akan membawa dampak negatif dalam bentuk meningkatnya resistensi dan efek samping. 
Idealnya antibiotik yang dipilih untuk pengobatan infeksi saluran kemih harus memiliki sifat-sifat yaitu dapat diabsorpsi dengan baik, ditoleransi oleh pasien, dapat mencapai kadar yang tinggi dalam urin, serta memiliki spektrum terbatas untuk mikroba yang diketahui atau dicurigai. Di dalam pemilihan antibiotik untuk pengobatan infeksi saluran kemih juga sangat penting untuk mempertimbangkan peningkatan resistensi E.coli dan patogen lain terhadap beberapa antibiotik. Resistensi E.coli terhadap amoksisilin dan antibiotik sefalosporin diperkirakan mencapai $30 \%$. Secara keseluruhan, patogen penyebab infeksi saluran kemih masih sensitif terhadap kombinasi trimetoprimsulfametoksazol walaupun kejadian resistensi di berbagai tempat telah mencapai $22 \%$. Pemilihan antibiotik harus memperhatikan riwayat antibiotik yang digunakan pasien (Coyle, 2005).

\section{METODE PENELITIAN}

Penelitian ini adalah penelitian survey dilakukan dengan rancangan deskriptif melalui penelusuran data secara retrospektif dari data rekam medik pasien Infeksi Saluran Kemih (ISK) di Rumah Sakit Samarinda Medika Citra (SMC).

Sampel dalam penelitian ini adalah pasien ISK yang menjalani pengobatan di Rumah Sakit Samarinda Medika Citra (SMC) periode Desember 2014 - Desember 2016 sebanyak 87 orang, dengan kriteria inklusi : a) Pasien dengan diagnosis utama ISK sepanjang periode Desember 2014 - Desember 2016, b) pasien ISK dengan atau tanpa penyakit penyerta.

Teknik pengumpulan data dalam penelitian ini adalah studi dokumentasi yaitu berupa catatan rekam medik pasien dengan diagnosis ISK selama periode Desember 2014 - Desember 2016. Pengumpulan data dimulai dari observasi secara retrospektif untuk kasus diagnosa ISK yang memenuhi kriteria inklusi

Berdasarkan dari hasil pengumpulan data, ditemukan sekian kasus pasien yang terdiagnosa ISK, kemudian dari kartu rekam medik dicatat karakteristik pasien yang meliputi usia, jenis kelami, penyakit pemyerta dan jenis ISK, selanjutnya dari kartu rekam medik dicatat ketepatan penggunaan antibiotik pada pasien ISK yang meliputi, tepat indikasi, tepat pemilihan obat, tepat dosis, tepat interval pemberian, 
tepat durasi pemberian, dan tepat rute pemberian kemudian dibandingkan dengan Pedoman Diagnosis dan Terapi Rumah Sakit Samarinda Medika Citra (SMC), dan yang terakhir dari kartu rekam medik dilakukan identifikasi efektivitas penggunaan antibiotik dengan parameter leukosuria, demam dan nyeri. Selanjutnya dianalisis secara deskriptif dan diambil kesimpulan.

\section{HASIL DAN PEMBAHASAN}

\section{Karakteristik Pasien ISK}

Tujuannya adalah untuk mengetahui gambaran karakteristik pasien ISK meliputi jenis kelamin, usia, penyakit penyerta, dan jenis ISK. Karakteristik pasien seperti jenis kelamin dan usia merupakan salah satu faktor yang dapat mempengaruhi individu terhadap suatu penyakit tertentu. Seperti hal nya pada penyakit ISK dimana angka kejadian pada wanita lebih besar dibandingkan pria, dan usia dewasa angka kejadian ISK lebih besar.

\section{Jenis Kelamin}

Tabel 1. Distribusi Jenis Kelamin Pasien Penderita ISK

\begin{tabular}{lcc}
\hline \multicolumn{1}{c}{ Jenis Kelamin } & Jumlah Pasien & Presentase \\
\hline Pria & 18 & $20,69 \%$ \\
Wanita & 69 & $79,31 \%$ \\
\hline Total & $\mathbf{8 7}$ & $\mathbf{1 0 0} \%$ \\
\hline
\end{tabular}

Dari 87 kasus pasien yang di rawat di Rumah Sakit Samarinda Medika Citra (SMC) sebanyak 20,69\% atau 18 kasus dialami oleh pasien pria dan 79,31\% atau 69 kasus dialami oleh pasien wanita.

Wanita cenderung lebih sering menderita ISK dibandingkan pria karena bakteri dapat menjangkau kandung kemih dengan lebih mudah pada wanita dibandingkan dengan pria. Panjang uretra pada wanita lebih pendek (sekitar 3-5 $\mathrm{cm}$ ) daripada uretra pria (sekitar $15-18 \mathrm{~cm}$ ), sehingga bakteri yang akan menyerang mempunyai jarak yang lebih pendek dan dekat untuk menginfeksi bagian saluran kemih. Uretra pada wanita letaknya juga berdekatan dengan rektum sehingga mikroorganime lainnya dapat dengan mudah menjangkau uretra dan menyebabkan infeksi. Selain itu cairan prostat pada pria juga memiliki sifat-sifat bakterisid 
sehingga menjadi pelindung terhadap infeksi oleh kuman-kuman uropatogen (Sukandar, 2009).

Hubungan seksual mungkin juga menjadi salah satu penyebab ISK pada wanita dikarenakan mikroorganisme dapat terdorong masuk ke uretra. Pemakaian suatu alat diafragma (alat kontrasepsi pencegah kehamilan) dapat berperan penting timbulnya infeksi karena diagfragma mendorong uretra secara berlawanan dan membuat uretra lebih sulit untuk mengosongkan kandung kemih dengan sempurna. Sehingga urin atau air seni yang tersisa didalam kandung kemih lebih mungkin menjadi tempat tumbuh dan berkembangnya mikroorganisme dan menyebabkan infeksi.

\section{Usia}

Tabel 2. Distribusi Usia Pasien Penderita ISK

\begin{tabular}{ccccc}
\hline \multirow{2}{*}{$\begin{array}{c}\text { Usia } \\
\text { (Tahun) }\end{array}$} & \multicolumn{2}{c}{ Pria } & \multicolumn{2}{c}{ Wanita } \\
\cline { 2 - 5 } & Jumlah & \% & Jumlah & \% \\
\hline $0-5$ & 2 & 2,3 & 4 & 4,6 \\
$12-16$ & 0 & 0 & 2 & 2,3 \\
$17-25$ & 1 & 1,15 & 22 & 25,2 \\
$26-35$ & 7 & 8,04 & 21 & 24,14 \\
$36-45$ & 2 & 2,3 & 8 & 9,2 \\
$46-55$ & 3 & 3,44 & 4 & 4,6 \\
$56-65$ & 3 & 3,44 & 4 & 4,6 \\
$>65$ & 0 & 0 & 4 & 4,6 \\
\hline Total & $\mathbf{1 8}$ & $\mathbf{2 0 , 6 7}$ & $\mathbf{6 9}$ & $\mathbf{7 9 , 3 3}$ \\
\hline
\end{tabular}

Dari 87 kasus pasien yang di rawat di Rumah Sakit Samarinda Medika Citra (SMC) angka kejadian ISK terbesar pada usia 17-25 tahun (25,5\%) dan 26-35 tahun $(24,14 \%)$ dengan jenis kelamin wanita.

Insiden ISK dapat menyerang pasien dari segala usia mulai bayi baru lahir hingga orang tua. Menjelang remaja hingga dewasa insiden ISK bertambah secara signifikan pada wanita mencapai $20 \%$. Faktor risiko yang utama yang berusia 1635 tahun adalah berkaitan dengan hubungan seksual (Nguyen, 2004). 


\section{Penyakit Penyerta}

Tabel 3. Distribusi Penyakit Penyerta Pasien Penderita ISK

\begin{tabular}{lcc}
\hline \multicolumn{1}{c}{ Diagnosa } & $\begin{array}{c}\text { Jumlah } \\
\text { Pasien }\end{array}$ & $\begin{array}{c}\text { Persentase } \\
(\mathbf{\%})\end{array}$ \\
\hline $\begin{array}{l}\text { ISK tanpa } \\
\text { penyakit penyerta }\end{array}$ & 60 & 69 \\
$\begin{array}{l}\text { ISK dengan } \\
\text { penyakit penyerta }\end{array}$ & 27 & 31 \\
\hline \multicolumn{1}{c}{ Total } & $\mathbf{8 7}$ & $\mathbf{1 0 0}$ \\
\hline
\end{tabular}

Dari 87 kasus pasien ISK sebanyak 69\% atau 60 kasus ISK tanpa penyakit penyerta dan sebanyak $31 \%$ atau 27 kasus ISK dengan penyakit penyerta. ISK dengan penyakit penyerta terbagi lagi sesuai dengan penyakit penyertanya, antara lain : hipertensi, diabetes melitus, anemia, dyspepsia, asma, wasir, kolik abdomen serta ISK pada kondisi hamil dan abortus incomplete.

Pasien diabetes berisiko mengalami komplikasi kronik makrovaskular diantaranya adalah infeksi. Pasien diabetes dengan kadar glukosa darah yang tinggi lebih rentan mengalami berbagai infeksi dibanding dengan pasien yang tidak menderita diabetes. Infeksi pada pasien diabetes umumnya terlokalisasi di saluran kemih (Black, 2009).

Infeksi saluran kemih lebih banyak terjadi pada pasien diabetes perempuan, karena secara anatomis uretra perempuan lebih pendek. Orifisium uretra dan vagina juga merupakan daerah yang mudah sekali terjadi kolonisasi bakteri (Black, 2009).

Gejala infeksi saluran kemih pada pasien diabetes umumnya asimtomatik, namun dapat berkembang menjadi simtomatik dan meningkatkan risiko untuk masuk rumah sakit dengan bakteremia hingga pielonefritis bilateral. Oleh karena itu, walaupun gejala infeksi saluran kemih pada pasien diabetes asimtomatik hal ini tidak dapat diabaikan (Saleem, 2011).

Infeksi saluran kemih pada pasien diabetes menurut beberapa hasil penelitian disebabkan berbagai faktor risiko. Faktor-faktor risiko infeksi saluran kemih pada pasien diabetes yaitu usia, lama menderita diabetes, indeks massa tubuh, hubungan seksual dan upaya pengendalian diabetes. Infeksi saluran kemih pada pasien 
diabetes umumnya terjadi pada pasien dengan pengendalian diabetes yang buruk dan adanya infeksi dapat memperburuk pengendalian glukosa darah (Black, 2009).

Kejadian ISK sering pula terjadi pada masa kehamilan. Perubahan mekanis dan hormonal yang terjadi pada kehamilan meningkatkan risiko keadaan yang membuat urin tertahan di saluran kencing. Juga adanya peningkatan hormon progesteron pada kehamilan akan menambah besar dan berat rahim serta mengakibatkan pengenduran pada otot polos saluran kencing.

Perubahan-perubahan tersebut mencapai puncak pada akhir trimester dua dan awal trimester tiga yang merupakan faktor yang memudahkan terjangkitnya ISK pada kehamilan. Saluran kemih yang pendek pada perempuan dan kebersihan daerah sekitar kelamin luar yang menjadi bagian yang sulit dipantau pada perempuan hamil akan mempermudah ISK.

\section{Jenis ISK}

Tabel 4. Distribusi Jenis ISK

\begin{tabular}{lcc}
\hline Diagnosa & $\begin{array}{c}\text { Jumlah } \\
\text { Pasien }\end{array}$ & $\begin{array}{c}\text { Persentase } \\
(\boldsymbol{\%})\end{array}$ \\
\hline ISK Atas & 67 & 77 \\
ISK Bawah & 20 & 23 \\
\hline Total & $\mathbf{8 7}$ & $\mathbf{1 0 0}$ \\
\hline
\end{tabular}

Pasien diklasifikasikan menjadi ISK atas dan ISK bawah. Angka kejadin ISK atas terbesar adalah ISK atas (77\%) dibandingakan ISK bawah (23\%).

\section{Kesesuaian Penggunaan Antibiotik}

Kesesuaian penggunaan obat menjadi salah satu hal yang paling penting untuk mencapai keberhasilan terapi, meliputi kesesuaian penggunaan jenis dan golongan obat serta dosis yang perlu diperhatikan. Keputusan untuk melakukan upaya terapi diambil setelah diagnosis ditegakkan dengan benar, agar obat yang dipilih memiliki efek terapi yang sesuai dengan jenis penyakitnya.

Tindakan pengobatan dilakukan dengan rasionalisasi dalam penggunaan obat-obatan terutama antibiotika. Pengobatan dikatakan rasional bila memenuhi beberapa kriteria tertentu, seperti ketepatan indikasi, ketepatan pemilihan obat, 
ketepatan cara pemakaian obat dan dosis obat serta ketepatan penilaian kondisi pasien.

Dampak negatif dari tidak sesuainya pemilihan antibiotika adalah resistensi. Pemilihan terapi antibiotika yang tepat sangat berpengaruh pada keberhasilan terapi yang dilakukan. Disamping itu, ketepatan terapi antibiotika sangat diperlukan untuk meminimalkan resiko terjadinya resistensi yang merupakan masalah besar dalam terapi antibiotika. Pemilihan antibiotika seharusnya mempertimbangkan kejadian resitensi yang sudah terjadi di rumah sakit dan mempertimbangkan kejadian resistensi yang kemungkinan selanjutnya akan terjadi.

\section{Jenis dan Golongan Antibiotika}

Tabel 5. Antibiotika yang digunakan pada Pasien Penderita ISK

\begin{tabular}{|c|c|c|c|c|c|}
\hline No & $\begin{array}{c}\text { Golongan } \\
\text { Obat }\end{array}$ & Jenis Obat & $\begin{array}{c}\text { Jumlah } \\
\text { kasus }\end{array}$ & $\begin{array}{c}\text { Persentase } \\
\text { Jenis } \\
\text { Obat }(\%)\end{array}$ & $\begin{array}{c}\text { Persentase } \\
\text { Gol. Obat } \\
(\%)\end{array}$ \\
\hline \multirow[t]{3}{*}{1} & Sefalosporin & Seftriakson & 40 & 42,11 & \\
\hline & Generasi & Sefotaksim & 3 & 3,16 & 47,37 \\
\hline & Ketiga & Sefiksim & 2 & 2,10 & \\
\hline \multirow[t]{2}{*}{2} & Kuinolon & Siprofloksasin & 35 & 36,84 & 41,05 \\
\hline & & Levofloksasin & 4 & 4,21 & \\
\hline \multirow[t]{2}{*}{3} & Penisilin & Amoksisilin & 3 & 3,16 & 4,21 \\
\hline & & Ampisilin & 1 & 1,05 & \\
\hline \multirow[t]{2}{*}{4} & $\begin{array}{l}\text { Kombinasi } \\
\text { Sefalosporin } \\
\text { dan } \\
\text { Penisilin }\end{array}$ & $\begin{array}{l}\text { Sefoperazone- } \\
\text { Sulbaktam }\end{array}$ & 7 & 7,37 & 7,37 \\
\hline & Total & & 95 & 100 & 100 \\
\hline
\end{tabular}

Berdasarkan hasil pengobatan dan penggunaan antibiotik pada pasien ISK dapat diketahui macam dan golongan antibiotika yang digunakan pada pasien di Rumah Sakit Samarinda Medika Citra (SMC) periode Desember 2014 - Desember 2016.

Tabel 5 menunjukkan bahwa antibiotika yang paling banyak digunakan yaitu seftriakson. Seftriakson adalah golongan sefalosporin generasi ketiga, dengan sifat antilaktamase dan umumnya aktif terhadap gram negatif dan sangat stabil terhadap betalaktamase. 
Tingginya penggunaan seftriakson kemungkinan disebabkan karena seftriakson memiliki waktu paruh yang lebih panjang dibandingkan sefalosporin yang lain, sehingga cukup diberikan satu kali sehari. Selain itu seftriakson yang dibeikan secara infus atau bolus sehari sekali tidak menunjukan perbedaan yang bermakna terhadap konsentrasi obat dalam darah, baik pada pasien dengan kondisi ginjal normal, maupun pada pasien dengan kondisi gangguan ginjal. Seftriakson juga memiliki kemampuan untuk berpenetrasi keseluruh jaringan dan melintasi sawar otak sebagai terapi penangangan infeksi berat. Seftriakson sebenarnya diindikasikan untuk infeksi saluran nafas bawah, infeksi saluran nafas atas, infeksi kulit dan jaringan lunak serta infeksi saluran kemih.

\section{Dosis Antibiotika}

Tabel 6. Dosis Antibiotika yang diberikan pada Pasien Penderita ISK

\begin{tabular}{|c|c|c|c|c|}
\hline No & Jenis Obat & $\begin{array}{c}\text { Jenis } \\
\text { Sedian }\end{array}$ & Jumlah Pasien & Dosis Pasien \\
\hline 1 & Seftriakson & Injeksi & $\begin{array}{c}19 \\
19 \\
1\end{array}$ & $\begin{array}{l}1 \times 1000 \mathrm{mg} \\
2 \times 1000 \mathrm{mg} \\
2 \times 800 \mathrm{mg}\end{array}$ \\
\hline 2 & Sefotaksim & Injeksi & $\begin{array}{l}1 \\
1 \\
1\end{array}$ & $\begin{array}{l}3 \times 330 \mu \mathrm{g} \\
3 \times 300 \mathrm{mg} \\
3 \times 500 \mathrm{mg}\end{array}$ \\
\hline 3 & Sefiksim & Sirup & $\begin{array}{l}1 \\
1 \\
\end{array}$ & $\begin{array}{l}2 \times 3 / 4 \text { cth } \\
2 \times 1 / 2 \text { cth }\end{array}$ \\
\hline 4 & Siprofloksasin & $\begin{array}{l}\text { Tablet } \\
\text { Infus }\end{array}$ & $\begin{array}{c}4 \\
\\
1 \\
26 \\
1 \\
4 \\
\end{array}$ & $\begin{array}{l}2 \times 500 \mathrm{mg} \\
2 \times 100 \mathrm{mg} \\
2 \times 200 \mathrm{mg} \\
2 \times 250 \mathrm{mg} \\
2 \times 400 \mathrm{mg}\end{array}$ \\
\hline 5 & Levofloksasin & $\begin{array}{l}\text { Tablet } \\
\text { Infus }\end{array}$ & $\begin{array}{l}3 \\
1\end{array}$ & $\begin{array}{l}1 \times 500 \mathrm{mg} \\
1 \times 500 \mathrm{mg}\end{array}$ \\
\hline 6 & Amoksisilin & $\begin{array}{l}\text { Sirup } \\
\text { Injeksi }\end{array}$ & $\begin{array}{l}1 \\
3\end{array}$ & $\begin{array}{l}3 \times 250 \mathrm{mg} / \mathrm{mL} \\
3 \times 250 \mathrm{mg}\end{array}$ \\
\hline 7 & Ampisilin & Injeksi & 1 & $3 \times 500 \mathrm{mg}$ \\
\hline 8 & $\begin{array}{l}\text { Kombinasi } \\
\text { Sefoperazone } \\
\text { Sulbaktam }\end{array}$ & Injeksi & 7 & $2 \times 1000 \mathrm{mg}$ \\
\hline
\end{tabular}


Dosis adalah takaran atau ukuran pemberian obat kepada pasien. Dosis sangat berperan penting dalam terapi penyembuhan pasien. Hal ini disebabkan bila ukuran dosis yang digunakan tidak sesuai maka terapi yang diberikan kepada pasien tidak akan terwujud karena takaran dosis yang tidak tepat. Dosis pada terapi sediaan antibiotik sangat berperan penting karena apabila dosis pada sediaan antibiotik tidak sesuai maka akan menyebabkan resistensi pada bakteri. Dosis dan yang diberikan pada pasien penderita penyakit ISK di Rumah Sakit Samarinda Medika Citra (SMC) dapat dilihat pada tabel 6.

\section{Ketepatan Penggunaan Antibiotik}

\section{Ketepatan Indikasi Penyakit}

Tabel 7. Ketepatan Indikasi Penyakit

\begin{tabular}{llcc}
\hline No & Ketepatan Indikasi & Jumlah Kasus & Persentase (\%) \\
\hline 1 & Tepat Indikasi & 87 & 100 \\
2 & Tidak tepat Indikasi & - & - \\
\hline & Jumlah & $\mathbf{8 7}$ & $\mathbf{1 0 0}$ \\
\hline
\end{tabular}

Pemberian obat diberikan sesuai terapi yang spesifik terapi obat terutama antibiotik yang diberikan untuk eradikasi infeksi harus sesuai dengan indikasi setiap pasien (Kemenkes RI, 2011). Terapi antibiotik dapat diberikan apabila pasien terdiagnosis infeksi atau terdapat tanda atau gejala infeksi.

Pada penelitian ini, sebagian besar pasien mengalami gejala yang menunjukan terjadinya infeksi saluran kemih. Pasien juga melakukan pemeriksaan laboratorium dengan sampel urin, yang menunjukan leukosuria, hematuria, positif nitrit dan bakteri yang artinya pasien terinfeksi bakteri pada area saluran kemih. Terapi yang sesuai dengan gejala yaitu terapi antibiotik dan berdasarkan tabel 7 ketepatan indikasi sebesar $100 \%$.

\section{Ketepatan Pemilihan Obat}

Tabel 8. Ketepatan Pemilihan Obat

\begin{tabular}{llcc}
\hline No & Ketepatan Obat & Jumlah Kasus & Persentase (\%) \\
\hline 1 & Tepat Obat & 83 & 95,40 \\
2 & Tidak tepat Obat & 4 & 4,60 \\
\hline & Jumlah & $\mathbf{8 7}$ & $\mathbf{1 0 0}$ \\
\hline
\end{tabular}


Pemilihan obat secara tepat berdasarkan diagnosis, kondisi pasien, dan spektrum mikroorganisme penginfeksi (Kemenkes RI, 2011) Pasien dengan indikasi infeksi saluran kemih dengan sebagian besar bakteri penyebab merupakan bakteri gram negatif maka terapi yang diberikan juga harus terapi antibiotik untuk bakteri gram negatif (spektrum sempit) namun apabila tidak dilakukan kultur bakteri pada urin maka dapat diberikan antibiotik spektrum luas (BPOM, 2014). Ketepatan dalam pemilihan obat perlu diperhatikan untuk mencegah terjadinya resistensi antibiotik (WHO, 2014). Berdasarkan pedoman diagnosis dan terapi di Rumah Sakit Samarinda Medika Citra (SMC), terapi untuk infeksi saluran kemih bawah yaitu ampisilin, trimetoprim-sufametoksazol, florokuinolon, sefpodoksim, dan amoksisilin-klavulanat selama 3 hari dengan terapi parenteral minimal 48 jam, namun apabila disertai leukosuria maka diberikan terapi konvensional selama 5-10 hari. Sedangkan terapi untuk infeksi saluran kemih atas yaitu sebagai terapi awal selama 48-72 jam diberikan secara parenteral sebelum diketahui mikroorganisme sebagai penyebabnya yaitu florokuinolon, aminoglikosida dengan atau tanpa ampisilin dan sefalosporin dengan spektrum luas dengsan atau tanpa aminoglikosida, ampisillin yang dikombinasi dengan gentamisin, ampicillin sulbaktam, dan trimetoprim-sulfametoksazol.

Berdasarkan tabel 8 ketepatan pemilihan obat pada pasien ISK di Rumah Sakit Samarinda Medika Citra Periode Desember 2014 - Desember 2016 sebesar 95\% atau 83 kasus dan ketidak tepatan pemilihann obat sebesar 4,60\% atau 4 kasus. Dikatakan tidak tepat karena pada 4 kasus tersebut diberikan injeksi seftriakson dan injeksi stabactam yang merupakan kombinasi sulfabaktam $\mathrm{Na}$ dan sefoperazone $\mathrm{Na}$, hal ini tidak sesuai dengan pedoman yang digunakan. Dimana berdasarkan pedoman yang digunakan seftriakson dan kombinasi sulfabaktam $\mathrm{Na}$ dan sefoperazone $\mathrm{Na}$ dindikasikan untuk infeksi saluran kemih atas. Namun dalam hal ini dokter memiliki pertimbangan lain dalam pemilihan antibiotik dimana antibiotik yang digunakan masih memiliki mekanisme kerja yang sama yaitu menghambat dinding sel dari bakteri pencetus penyakit. Ketidak sesuaian yang terjadi bukan melanggar dari pedoman yang ada namun pemilihan antibiotik yang digunakan 
masih dalam satu turunan atau memiliki mekanisme kerja yang sama terhadap bakteri.

Namun berdasarkan Permenkes (2011), penggunaan antibiotik golongan aminoglikosida dan kuinolon untuk pasien ISK dengan penyakit penyerta diabetes melitus tidak tepat karena dapat meningkatkan efek hipoglikemik dari obat antidiabetik oral, jadi sebaiknya antibiotik tersebut tidak diberikan pada pasien ISK dengan penyakit penyerta diabetes mellitus.

\section{Ketepatan Dosis}

Tabel 9. Ketepatan Dosis

\begin{tabular}{llcc}
\hline No & Ketepatan Dosis & Jumlah Kasus & Persentase (\%) \\
\hline 1 & Tepat Dosis & 87 & 100 \\
2 & Tidak tepat Dosis & - & - \\
\hline & Jumlah & $\mathbf{8 7}$ & $\mathbf{1 0 0}$ \\
\hline
\end{tabular}

Penatalaksanaan terapi untuk infeksi saluran kemih, setiap pasien harus memenuhi ketepatan dosis sehingga efek terapi yang diharapkan dapat tercapai (Humaida, 2014).

Pemberiaan antibiotik dengan dosis berlebih dapat meningkatkan resiko terjadinya efek samping pada pasien. Pemberiaan antibiotik dengan dosis yang kurang akan mengakibatkan tidak tercapainya efek terapi yang diinginkan dan antibiotik menjadi tidak berefek karena tidak mencapai KHM (Kadar Hambat Minimum) sehingga mikroorganisme yang menginfeksi tidak mati. Pemberiaan dosis yang tidak tepat dapat meningkatkan resiko resistensi bakteri yang tersisa dalam tubuh (Lisni, 2015).

Dalam upaya mencegah terjadinya resistensi antibiotik, pemberian dosis harus disesuaikan dengan kondisi tiap individu, keparahan infeksi, mikroorganisme yang menyebabkan, profil farmakokoinetik dan farmakodinamik obat tersebut. Selama terapi dengan dosis tertentu diberikan kepada pasien, perlu dilakukan monitoring berkelanjutan untuk melihat pencapaian terapi setelah pemberian antibiotik dengan dosis tersebut sehingga dapat menentukan perlu atau tidaknya penyesusaian dosis kembali (With, 2016). 
Berdasarkan tabel.9 ketepatan pemilihan obat pada pasien ISK di Rumah Sakit Samrinda Medika Citra Periode Desember 2014 - Desember 2016 sebesar $100 \%$ berdasarkan pedoman yang digunakan rumah sakit.

\section{Ketepatan Interval Pemberian}

Tabel 10. Ketepatan Interval Pemberian

\begin{tabular}{llcc}
\hline No & Ketepatan Interval & Jumlah Kasus & Persentase (\%) \\
\hline 1 & Tepat Interval Pemberian & 87 & 100 \\
2 & $\begin{array}{l}\text { Tidak tepat interval } \\
\text { pemberian }\end{array}$ & - & - \\
\hline Jumlah & $\mathbf{8 7}$ & $\mathbf{1 0 0}$ \\
\hline
\end{tabular}

Dalam pemberian terapi antibiotik perlu memperhatikan interval waktu pemberian antibiotik kepada pasien. Interval waktu pemberian merupakan jarak waktu dari pemberiaan antibiotik yang pertama dengan pemberiaan ke dua, ke tiga, dan selanjutnya (Kemenkes, 2011). Hal ini perlu diperhatikan untuk mencegah kadar antibiotik dalam darah kurang dari kadar terapetik yang memungkinkan bakteri dapat kembali beregenerasi dan menjadi resisten terhadap antibiotik terapi (Amin, 2014).

Menurut Kemenkes (2011), pemberian interval yang tidak tepat pada terapi antibiotik dapat menyebabkan mikroorganisme menjadi beregenerasi menjadi lebih kuat sehingga menjadi resisten terhadap antibiotik yang diberikan, selain itu aktivitas antibiotik dalam tubuh akan tidak maksimal.

Leekha (2011), mengungkapkan aktivitas farmakodinamik antibiotik bergandung pada konsep antibiotik time-dependent $v$ s concentration-dependent, artinya kerja antibiotik akan maksimal apabila interval pemberian antibiotik tepat.

Berdasarkan tabel 10 ketepatan interval waktu pemberiaan pada pasien ISK di Rumah Sakit Samrinda Medika Citra Periode Desember 2014 - Desember 2016 sebesar $100 \%$ berdasarkan pedoman yang digunakan rumah sakit.

\section{Ketepatan Durasi Pemberian}

Pemberian antibiotik harus selalu memperhatikan durasi atau lama pemberian antibiotik, apabila durasi pemberiaan tidak tepat dapat mempengaruhi hasil 
pengobatan pasien. Antibiotik merupakan salah satu obat yang durasi pemberiannya harus diperhatikan agar bakteri penyebab ISK dapat terbunuh seluruhnya sehingga resiko resistensi antibiotik dapat diturunkan (White, 2011).

Tabel 11. Ketepatan Durasi Pemberian

\begin{tabular}{llcc}
\hline No & Ketepatan Durasi & Jumlah Kasus & Persentase (\%) \\
\hline 1 & $\begin{array}{l}\text { Tepat Durasi } \\
\text { Pemberian }\end{array}$ & 82 & 94,25 \\
2 & $\begin{array}{l}\text { Tidak tepat Durasi } \\
\text { pemberian }\end{array}$ & 5 & 5,75 \\
\hline & Jumlah & $\mathbf{8 7}$ & $\mathbf{1 0 0}$ \\
\hline & Berdasarkan tabel 11 & menunjukan sebesar $94,25 \%$ & ketepatan durasi
\end{tabular}

pemberian antibiotik dan sebesar $5,75 \%$ ketidak tepatan durasi pemberian antibiotik berdasarkan pedoman yang digunakan rumah sakit.

Ketidak tepatan durasi yang dimaksud adalah lama pemberiaan yang kurang atau terlalu cepat sehingga terapi yang dijalani pasien terlalu singkat. Robinson (2014) menyatakan bahwa durasi terapi antibiotik ISK minimal 72 jam apabila kurang dari 72 jam terapi dihentikan dapat menyebabkan keterulangan infeksi sebab bakteri penyebab ISK belum terbunuh sepenuhnya. Ketidak tepatan lama pemberian terapi antibiotik dapat terjadi karena kondisi pasien yang telah membaik, faktor finansial pasien serta pihak keluarga pasien meminta untuk pulang.

\section{Ketepatan Rute Pemberian}

Tabel 12. Ketepatan Rute Pemberian

\begin{tabular}{|c|c|c|c|c|}
\hline No & Ketepatan $\mathrm{F}$ & ute & Jumlah Kasus & Persentase (\%) \\
\hline 1 & $\begin{array}{l}\text { Tepat } \\
\text { Pemberian }\end{array}$ & Rute & 83 & 95,45 \\
\hline 2 & $\begin{array}{l}\text { Tidak tepat } \\
\text { Pemberian }\end{array}$ & Rute & 4 & 4,60 \\
\hline & Jumlah & & 87 & 100 \\
\hline
\end{tabular}

Berdasarkan tabel 12 menunjukan sebesar 95,40\% ketepatan rute pemberian antibiotika dan sebesar $4,60 \%$ ketidak tepatan rute pemberian antibiotika berdasarkan pedoman yang digunakan rumah sakit.

Ketidak tepatan rute pemberian yang dimaksud yaitu berdasarkan pedoman yang digunakan rumah sakit Samarinda Medika Citra (SMC) sebagai terapi awal untuk ISK diberikan antibiotika secara parenteral selama 48-72 jam, sedangkan 
untuk 4 kasus terapi awal untuk ISK diberikan secara peroral. Hal ini mungkin terjadi karena keadaan pasien memungkinkan untuk menggunakan obat secara peroral. Selain itu beberapa antibiotika juga dapat diserap dengan baik pada pemberian peroral dan efektif untuk ISK (Kemenkes RI, 2014).

\section{Kesesuaian Penggunaan Antibiotik pada pasien ISK}

Tabel 13. Kesesuaian Penggunaan Penggunaan obat Antibiotik Pada Pasien ISK

\begin{tabular}{llcc}
\hline No & Keterangan & Jumlah Kasus & Persentase (\%) \\
\hline 1 & Sesuai & 74 & 85 \\
2 & Tidak Sesuai & 13 & 15 \\
\hline & Jumlah & $\mathbf{8 7}$ & $\mathbf{1 0 0}$ \\
\hline
\end{tabular}

Kesesuaian penggunaan antibiotika pada pasien ISK di Rumah Sakit Samarinda Medika Citra (SMC) belum sepenuhnya sesuai dengan pedoman diagnosis dan terapi Rumah Sakit Samarinda Medika Citra (SMC).

Berdasarkan tabel 13 persentase penggunaan obat antibiotika yang sesuai yaitu sebesar $85 \%$ dan yang tidak sesuai sebesar $15 \%$.

\section{Efektivitas Penggunaan Antibiotik}

Tabel 14. Efektivitas Penggunaan Obat Antibiotika pada Pasien ISK dengan Parameter Leukosuria dan Suhu

\begin{tabular}{|c|c|c|c|c|c|c|c|}
\hline \multirow{2}{*}{$\begin{array}{c}\text { Parameter } \\
\text { Terapi }\end{array}$} & \multirow{2}{*}{$\begin{array}{c}\text { Nilai } \\
\text { normal }\end{array}$} & \multicolumn{2}{|c|}{ Awal } & \multirow[b]{2}{*}{$\%$} & \multicolumn{2}{|c|}{ Akhir } & \multirow[b]{2}{*}{$\%$} \\
\hline & & Normal & $\begin{array}{c}\text { Diatas } \\
\text { Normal }\end{array}$ & & Normal & $\begin{array}{c}\text { Diatas } \\
\text { Normal }\end{array}$ & \\
\hline Leukosuria & $\begin{array}{c}1- \\
6 / \mathrm{LPB} \\
36-37,5\end{array}$ & - & 25 & 100 & 25 & - & 100 \\
\hline Suhu & ${ }^{0} \mathrm{C}$ & - & 38 & 100 & 38 & - & 100 \\
\hline
\end{tabular}

Tabel 15. Efektivitas Penggunaan Obat Antibiotik dengan Parameter Nyeri

\begin{tabular}{|c|c|c|}
\hline $\begin{array}{c}\text { Parameter } \\
\text { Terapi }\end{array}$ & Awal & Akhir \\
\hline Nyeri & $\begin{array}{ll}87 & \text { kasus } \\
\text { mengeluhkan nyeri }\end{array}$ & $\begin{array}{l}87 \text { kasus berkurang } \\
\text { rasa nyeri dan hilang }\end{array}$ \\
\hline
\end{tabular}

Efektivitas antibiotik adalah pengukuran keberhasilan penggunaan antibiotik pada pasien guna meningkatkan taraf hidup dari pasien. Efektivitas penggunaan antibiotik sendiri dapat diloihat berdasarkan keberhasilan dalam menyembuhkan 
pasien. Berdasarkan obat-obatan yang digunakan pada terapi Infeksi Saluran Kemih (ISK) di Rumah Sakit Samarinda Medika Citra (SMC) terdapat berbagai macam variasi antibiotik yang digunakan pada pasien. Berdasarkan hasil penelitian dilapangan didapatkan bahwa antibiotik golongan sefalosporin generasi ketiga yaitu seftriakson dan antibiotik golongan kuinolon yaitu siprofloksasin yang banyak digunakan sebagai terapi. Tabel efektivitas penggunaan antibiotik pada pasien ISK di Rumah Sakit Samarinda Medika Citra (SMC) periode Desember 2014 Desember 2016 dapat dilihat pada tabel 14 dan 15

Dari tabel 14 dan tabel 15 dapat dilihat bahwa parameter yang digunakan adalah leukosuria dari pasien serta suhu tubuh dari pasien selain itu parameter lain yang digunakan adalah nyeri yang diderita pasien. Leukosuria atau piuria merupakan salah satu petunjuk penting terhadap dugaan adanya ISK. Leukosuria dinyatakan positif bilamana terdapat lebih dari 6 leukosit/Lapang Pandang Besar (LPB) sedimen air kemih. Dari 87 kasus tidak semua pasien melakukan uji urinalisa secara berkala. Hal ini mungkin disebabkan karena jumlah leukosit pada pemeriksaan awal sudah di batas normal sehingga tidak dilakukan lagi pemeriksaan ulang. Namun ada pula pada pemeriksaan awal jumlah leukosit di atas batas normal, tetapi tidak dilakukan pemeriksaan ulang. Hal ini mungkin terjadi disebabkan oleh biaya yang mahal dalam pemeriksaan laboratorium. Parameter selanjutnya demam yang dapat dilihat dari suhu atau temperatur tubuh pasien. Bila infeksi di dalam tubuh terjadi maka suhu tubuh akan meningkat seiring besarnya infeksi menyebar hal ini merupakan sistem pertahanan tubuh guna mengetahui seberapa jauh infeksi terjadi. Parameter terakhir adalah nyeri, nyeri digunakan sebagai parameter karena sebagian besar penderita ISK mengeluhkan nyeri khususnya pada perut bagian bawah atau saat buang air kecil serta nyeri pinggang. Oleh sebab itu nyeri dapat digunakan sebagai parameter selain leukosuria dan demam. Dari tabel diatas didapatkan hasil bahwa 100\% pasien mengalami pemulihan yaitu di tandai dengan kembalinya kadar leukosuria ke batas normal, kembalinya suhu tubuh kekeadaan normal dan rasa nyeri yang berkurang dan hilang setelah mendapatkan terapi.

Keberhasilan dari terapi disini bukan dilihat dari dan hilangnya bakteri secara menyeluruh melainkan hilangnya gejala-gejala dari ISK. Selain itu evaluasi ulang 
perlu untuk dilakukan dengan kecurigaan adanya kelainan anatomi atau struktural dapat mulai dipertimbangkan bila terjadi ISK berulang kali dalam waktu 6 bulan. Hal ini dilakukan guna meningkatkan taraf hidup dari pasien.

\section{KESIMPULAN}

Berdasarkan hasil penelitian yang didapatkan, maka dapat diambil kesimpulan dari penelitian ini adalah :

a. Angka kejadian ISK terbesar pada jenis kelamin wanita (79\%) dibandingkan jenis kelamin pria (79\%) dengan rentan usia 17 tahun - 35 tahun. Angka kejadian ISK tanpa penyakit penyerta (69\%) lebih besar dibandingkan angka kejadian ISK tanpa penyakit penyerta (31\%), begitu pula angka kejadia ISK atas (77\%) lebih besar dibandingkan ISK bawah (23\%).

b. Kesesuaian penggunaan antibiotika pada pasien ISK di Rumah Sakit Samarinda Medika Citra (SMC) belum sepenuhnya sesuai dengan pedoman diagnosis dan terapi Rumah Sakit Samarinda Medika Citra (SMC).

c. Efektivitas penggunaan antibiotika pada pasien ISK di Rumah Sakit Samarinda Medika Citra (SMC) sepenuhnya efektif berdasarkan kondisi pasien

\section{DAFTAR PUSTAKA}

Amin, L.Z. 2014. Pemilihan Antibiotik yang Rasional. Medicinus, 27(3), 40-15

Barry M. J. et al. 2011. UA Guideline on Management of Benign Prostate Hyperplasia.The Journal of Urology, Vo1.185.

Bint, A. J dan Berington, A. W. 2003.Urinary Tract Infection, in Walker, R., Edward, C. (Eds.),Clinical Pharmacy and Therapeutics, 3 edition. Churchill Livingstone : London.

Black, J.M. \& Hawks, J.H. 2009.Medical-surgical nursing. Clinical management for positive outcomes. Eighth edition. St. Louis : Saunders, an imprint of Elsevier, Inc.

Coyle, E.A dan Prince, R. A. 2005. Urinary Tract Infection, in Dipiro J.T., et al, Pharmacotherapy A Pathophysiologic Approach, $6^{\text {th }}$. Appleton\&Lange, Stamford.

Dipiro, J.t., Wells, B.G., Dipiro, C.V., Schwinghammer, T. L. 2015. Pharmacotherapy Handbook. Ninth Edition. USA: McGraw-Hill Education

Gilman dan Goodman. 2011. The Pharmacological Basis Of Therapeutic 12 Edition. New York: Mc Graw Hill Medical

Humaida, R. 2014. Strategy to Handle Resintance Of Antibiotics. J Majority, 3(7), $133-120$ 
Katzung, MD, PhD dan Bertram. 2010. Farmakologi Dasar dan Klinik.Edisi 10.Jakarta: EGC

Kementrian Kesehatan RI. 2011. Modul Penggunaan Obat Rasional. Jakarta: Kemenkes RI

Kementrian Kesehatan RI. 2011. Pedoman Pelayanan Kefarmasian Untuk Terapi Antibiotik. Jakarta: Kemenkes RI

Kementrian Kesehatan RI. 2014. Peraturan Mentri Kesehatan Republik Indonesia Nomer 5 Tahun 2014 tentang Pedoman Praktik Klinis Bagi Dokter di Fasilitas Kesehatan Primer. Jakarta

Leekha, S, et al. 2011. General Principles af Antimicrobial Therapy. Mayo Clin Pro., 86(2):156-167

Lisini, I, et al. 2015. Evaluasi Penggunaan Antibiotik Pada Pasien Faringitis di Rumah sakit di Kota Bandung. Jurnal Farmasi Galenika. Vol. 02. No. 01. 43-45

Neal, M.J. 2006. At a Glance Farmakologi Medis Edisi Kelima. Jakarta: Erlangga

Nguyen HTMD. Bacterial Infection of TheGenitourinary Tract.p: 193-218.Dalam Brounwald E, Fauci AS,Kasper DL, Huser SL, Longo DL,Jameson JL.2003. HarisonPrinciple of Internal Medicine $15^{\text {th }}$ Edition. McGrawhill. USA

Pranoto, Eko. et al. 2012. Infeksi Saluran Kemih di Instalasi Rawat Inap RSUD Banyumas. Jurnal Pharmacy. Vol 9. No. 02. ISSN 1693-3591

Robinson, J.L. et al. 2014. Urinary Tract Infection in Infants and Chilidren: Diagnosis and Management. Paediatr Child Health, 9(6), 315-19

Saleem M. \& Daniel, B. 2011. Prevalence of urinary tract infection among patients with diabetes in Bangalore City. International Journal of Emerging. Sciences, 1(2), 133-142

Siregar,Charles J.P. 2004. Farmasi Rumah Sakit : teori dan penerapan. EGC : Jakarta.

Speakman M. J. 2008. Lower Urinary Tract Symptom Suggestive of Benign Prostate Hyperplasia (LUTS/BPH) : More Than Treating Symptoms. European Urology Supplements 7th Edition.680-589.

Sukandar, E. 2004. Infeksi Saluran Kemih Pasien Dewasa. Buku Ajar Ilmu Penyakit Dalam, Jilid I. Jakarta: Balai Penerbit FK UI. Hal:553-557

Suwitra.K dan Mangatas. 2004. Penyakit Ginjal Kronik. Buku Ajar Ilmu Penyakit Dalam.Jilid 1. Edisi Keempat. Jakarta: FK UI

White, B. 2011. Diagnosis and Treatment of Urinary Tract Infection in Children . Am Fam Physician. 83(4). 409-415

With, K. D, et al. 2016. Strategies to Enhance Rational Use of Antibiotics in Hospital: A Guideline by the German Society for Infectious Diseases. Infection. 44, 395-439

World Healh Organization (WHO). 2014. Antimicrobial Resistence. Global Report on Survellance. World Healh Organization. 